Dr. sc. Nataša Žunić-Kovačević i dr. sc. Marko Šikić: Upravnopravni pojam zastare s posebnim... Zbornik radova Pravnog fakulteta u Splitu, god. 55, 1/2018., str. 231.- 250.

\author{
Dr. sc. Nataša Žunić-Kovačević, profesorica
} dr. sc. Marko Šikić, izvanredni profesor

\title{
UPRAVNOPRAVNI POJAM ZASTARE S POSEBNIM OSVRTOM NA ZASTARU U POREZNOM PRAVU
}

\author{
UDK: 342.9 \\ Primljeno: 15. 12. 2017. \\ Pregledni rad
}

\begin{abstract}
U radu se, nakon uvodnog dijela u kojem se u najkraćim crtama prikazuje institut zastare u pravnoj teoriji i pojedinim pravnim granama, nastoji ukazati na posebnosti uređenja instituta zastare u upravnom pravu. Pri tome se posebno naglašava činjenica da su javnopravna tijela u upravnom odnosu u nadređenom položaju u odnosu na ostale sudionike tog odnosa. Također, navode se i pojedina načela upravnog prava kao naročito važna za shvaćanje posebnosti instituta zastare u upravnom pravu. Središnji i opsegom najveći dio rada posvećen je analizi instituta zastare u poreznom pravu, kroz odabrane primjere iz sudske prakse, pri čemu je najveća pozornost usmjerena na normativne izmjene instituta zastare učinjene odredbama najnovijeg Općeg poreznog zakona. U zaključku rada ukratko se iznose osnovne teze rada te nada da će primjena novog zakona dovesti do ostvarenja poreznopravne izvjesnosti i sigurnosti.
\end{abstract}

Ključne riječi: zastara, upravno pravo, porezno pravo, sudska praksa, Opći porezni zakon

\section{UVOD}

Institut zastare (lat. praescriptio, engl. prescription, statute of limitations, limitation, njem. Verjährung) svoje korijenje nalazi još u rimskome pravu. U njemu se isticalo kako zastarom tužbe pravo u načelu ne utrnjuje, ali se ne može više sudskim putem utjerivati. Također, razlikovao se prekid od mirovanja zastare $-\mathrm{u}$ prvom slučaju dio roka koji je isticao prije roka propada, pa će zastara, kada se ispune svi potrebni uvjeti, početi ponovno teći iz početka, dok mirovanje zastare jest period u kojem zastarni rok ne teče zbog određenih razloga, a onda kada ti razlozi prestanu, rok se ponovno nastavlja, uz pribrajanje ranije isteklog vremena. ${ }^{1}$

Teorija države i prava institut zastare shvaća u prvom redu kao gubitak sudske zaštite, a ne kao gubitak samog subjektivnog prava (koje i dalje može egzistirati kao „golo pravo“ - nudum ius). Ističe se specifično postupovno značenje zastare te naglašava njen značaj u zaštiti subjektivnih prava i opće pravne sigurnosti ${ }^{2}$ „... pretpostavlja se da ovlaštenik nema više interesa, nakon toliko vremena, za

V. Romac, Ante, Rimsko pravo, Pravni fakultet, Zagreb, 1998., str. 469.

2 V., tako, Vrban Duško, Država i pravo, Golden marketing, Zagreb, 2003., str. 343., i Visković, Nikola, Teorija države i prava, Birotehnika, Zagreb, 2001., str. 227. i 228. Isticanje činjenice kako se 
Dr. sc. Nataša Žunić-Kovačević i dr. sc. Marko Šikić: Upravnopravni pojam zastare s posebnim... Zbornik radova Pravnog fakulteta u Splitu, god. 55, 1/2018., str. 231.- 250.

ostvarenje svog pravnog ovlaštenja - tako da mu se zastara nameće kao neka vrsta kazne zbog nebrige, ali s druge strane je svrha zastare i dati sigurnost obvezanoj osobi da ne mora više brinuti zbog mogućnosti zakašnjelog potraživanja ovlaštenika. "3

Dakako, institut zastare u modernim pravnim porecima poznaju sve pravne grane i područja prava.

U građanskom se pravu, tako, ističe kako je ,zastara gubitak zahtjeva zbog nevršenja sadržaja subjektivnog prava kroz zakonom određeno vrijeme“". Navodi se kako kod instituta zastare dolazi do punog izražaja utjecaj vremena na pravne odnose te kako vrijeme u pravu može djelovati konstruktivno ili destruktivno. ${ }^{5} \mathrm{U}$ zastari je, jezgrovito se zaključuje, ,izražena misao da je ono što je faktički već uklonjeno - potpuno zrelo da i pravno propadne... smisao zastare nalazimo i u tome da se sadašnje zaštiti protiv prošlog. "6. Građanskopravna teorija ističe i kako se nastupom zastare u pravilu ne gasi samo pravo tj. kako zastarom samo prestaje pravo zahtijevati ispunjenje obveze. ${ }^{7}$ Također, od velike je važnosti kako se u građanskom pravu smisao instituta zastare nalazi u zaštiti dužnika: „Kada institut zastare ne bi postojao, dužnik koji je uredno ispunio svoju obvezu cijeli bi život morao čuvati dokaze o ispunjenju, i stalno bi bio izvrgnut opasnosti da ga netko tuži radi obveze dospjele $\mathrm{i}$ ispunjene davno u prošlosti. "8 Nadalje, građanskopravna teorija u institutu zastare pronalazi i ideju zaštite pravne sigurnosti te ističe da je njen smisao u mirenju dva suprotstavljena interesa - vjerovnikovog da ostvaruje svoje pravo te dužnikovog da ne bude nerazumno dugo u neizvjesnosti od mogućih vjerovnikovih pretenzija. ${ }^{9}$

U kaznenom se pravu, pak, razlikujući zastaru izvršenja kaznenopravnih sankcija i zastaru kaznenog progona, ističe kako je razlog postojanja instituta zastare prihvaćanje stajališta da izvršenje kaznenopravne sankcije nakon određenog vremena gubi smisao te kako nakon proteka određenog roka kazneno djelo pada u

zastarom u pravilu ne gasi samo pravo v. i u: Klarić, Petar, Vedriš, Martin, Građansko pravo, Narodne novine, Zagreb, 2006., str. 185.

3 Visković, op. cit. (bilj. 2), str. 227.

4 V. Klarić i dr., op. cit. (bilj. 2), str. 182.

5 Ibid.

6 Ibid.

7 Ibid., str. 185.

8 Pravni leksikon, Leksikografski zavod Miroslav Krleža, Zagreb, 2007., str. 1822.

9 „Zastara kao pravni institut obveznog prava s jedne strane potiče vjerovnika da vodi računa o svojim pravima i na vrijeme ih ostvaruje, a s druge strane služi pravnoj sigurnosti kako dužnik ne bi bio u neizvjesnosti oko postojanja svoje obveze i mogućih vjerovnikovih pretenzija. Radi se zapravo o sukobu dvaju interesa - onog vjerovnikovog da ostvaruje svoje pravo te dužnikovog da ne bude nerazumno dugo spreman na zaštitu od mogućih vjerovnikovih, opravdanih ili neopravdanih, pretenzija. U tom sukobu interesa zakonodavac je pokušao naći pravu mjeru propisujući rokove za nastupanje zastare, različite za pojedina potraživanja i među različitim subjektima, te propisujući početak zastarijevanja, uz načine prekida preskripcije i ostalo.“ Giunio, Miljenko Appio, „Zastarijevanje tražbine, zastara i posljedice opća i neka izabrana pitanja“, u: Liber amicorum Petar Klarić, uredili: Tatjana Josipović, Igor Gliha, Marko Baretić, Saša Nikšić, Marko Petrak, Tomislav Karlović, Pravni fakultet Sveučilišta u Zagrebu, Zagreb, 2012., str. 563-564. 
Dr. sc. Nataša Žunić-Kovačević i dr. sc. Marko Šikić: Upravnopravni pojam zastare s posebnim... Zbornik radova Pravnog fakulteta u Splitu, god. 55, 1/2018., str. 231.- 250.

zaborav te prema njemu postaju ravnodušni i javnost, pa i sama žrtva. ${ }^{10} \mathrm{U}$ pogledu zastare kaznenog progona teoretičari ističu njezinu dvostruku pravnu prirodu $-\mathrm{s}$ jedne strane ona predstavlja razlog gašenja državnog „prava kažnjavanja“ - pa bi stoga bila materijalnopravne naravi, dok bi s druge strane ona značila samo gašenje mogućnosti ostvarenja toga prava - pa bi onda bila postupovnopravne naravi. ${ }^{11}$

Dakako, pored građanskog i kaznenog prava, institut zastare poznaju i druge pravne grane: radno i službeničko pravo, prekršajno pravo, ${ }^{12}$ trgovačko pravo i dr.

U radu ćemo podrobnije analizirati institut zastare u upravnom pravu, a posebnu ćemo pozornost posvetiti analizi instituta zastare u poreznom pravu.

\section{UPRAVNOPRAVNI POJAM ZASTARE}

Raznolikost odnosa koji uređuju norme upravnog prava ogleda se i u uređenju instituta zastare. U pojedinim je zakonima zastara, tako, uređena vođena građanskopravnom logikom ili/i izričitim pozivanjem na odredbe Zakona o obveznim odnosima ${ }^{13} \mathrm{u}$ drugima se, pak, zastara odnosi na prekršajne ili disciplinske mjere pa je prisutan kaznenopravni pristup, ${ }^{14}$ dok je u trećoj grupi zakona zastara razvijena $\mathrm{u}$ posebnom upravnopravnom obliku. ${ }^{15}$

Mislimo da je uređenje zastare u poreznom pravu najčišći i najrazvijeniji primjer upravo navedenog posebnog, upravnopravnog, oblika uređenja zastare. Zbog toga ćemo (a i, dakako, zbog velike važnosti koju zastara ima u poreznom pravu) u posebnim poglavljima rada institut zastare u poreznom pravu podrobnije razmotriti. No, prije toga ćemo pokušati prikazati širi upravnopravni kontekst instituta zastare, odnosno razjasniti zašto smatramo da postoje posebna obilježja zastare u upravnom pravu koja su svojstvena isključivo navedenoj pravnoj grani.

Držimo, tako, kako je polazište za promatranje instituta zastare u upravnom pravu kao posebnog oblika tog instituta u samoj prirodi upravnopravnog odnosa. Upravnopravni odnos, kao posebni oblik pravnog odnosa, naime, karakterizira činjenica da je jedna od strana u tom odnosu tijelo javne uprave te da je takvo tijelo

10 Ibid., str. 1823.

11 Krapac, Davor, Kazneno-procesno pravo, Narodne novine, Zagreb, 2007., str. 40.

12 „U prekršajnom pravu institut zastare uvodi se radi pravne sigurnosti počinitelja prekršaja u tom smislu što on mora imati sigurnost da se nakon isteka određenog roka postupak protiv njega više neće moći pokrenuti, odnosno da se neće moći pristupiti izvršenju već izrečene kazne." Borković, Ivo, Upravno pravo, Narodne novine, Zagreb, 2002., str. 552.

13 V. npr. čl. 59-61. Zakona o koncesijama (NN 69/17) i čl. 170. Zakona o mirovinskom osiguranju (NN 157/13, 151/14, 33/15, 93/15 i 120/16).

14 V. npr. čl. 109. Zakona o policiji (NN 34/11, 130/12, 89/14, 151/14, 22/15 i 121/16) i čl. 109. i 111. Zakona o državnim službenicima (NN 92/2005, 140/2005, 142/2006, 77/2007, 107/2007, 27/2008, 34/2011, 49/2011, 150/2011, 34/2012, 38/2013, 37/2013, 1/2015, 138/2015, 61/2017).

15 Institut zastare uređen je i temeljnim postupovnim zakonom u grani upravnog prava, Zakonom o općem upravnom postupku (NN 47/09, u nastavku rada: ZUP). Čl. 135. st. 3. ZUP-a, naime, propisuje zastaru izvršenja rješenja jer određuje da se rješenje ne može izvršiti ako je isteklo pet godina od dana kada je rješenje postalo izvršno. 
u odnosu na ostale subjekte tog odnosa u nadređenom položaju. Drugim riječima, upravnopravni odnos ne zasniva se dogovorom stranaka niti suglasnošću njihovih volja već tijela javne uprave u tom odnosu istupaju s atributom vlasti (ius imperii). ${ }^{16}$

Navedena okolnost izražena je u ZUP-u i mogućnošću da tijela javne uprave postupke pokrenu po službenoj dužnosti svaki put kada tako propisuje zakon, kao i u svakoj situaciji kada utvrde da je pokretanje postupka nužno radi zaštite javnog interesa. ${ }^{17}$ Vođenje postupaka po službenoj dužnosti obilježava mnoga posebna upravna područja (pa tako i porezno pravu u poreznim upravnim postupcima) i prevladavajuć je u grani upravnog prava.

Nadalje, potrebno je istaknuti i neka od zakonom uspostavljenih načela upravnog prava i upravnog postupka za koja smatramo da su od posebne važnosti za institut zastare - načelo učinkovitosti i ekonomičnosti ${ }^{18}$ i načelo zaštite stečenih prava stranaka. ${ }^{19}$

Načelo učinkovitosti i ekonomičnosti zahtijeva da javnopravno tijelo provede postupak što brže, uz što manje troškova, kako bi stranka što prije ostvarila svoja prava, ali i kako bi se stranci što prije nametnule obveze - dakle u postupku se nastoje minimalizirati troškovi kako za stranke, tako i za tijelo javne uprave koje takve postupke vodi. Međutim, načelo učinkovitosti i ekonomičnosti nikako ne smije ići na štetu načela materijalne istine ${ }^{20}$ tj. potpunog i pravilnog utvrđenog činjeničnog stanja te donošenja zakonitog i pravilnog rješenja. ${ }^{21}$

Načelom zaštite stečenih prava stranaka, pak, utvrđuje se pravomoćnost rješenja tj. nedopustivost ponovnog odlučivanja o stvari koja je već riješena kao i neizmjenjivost odluke u toj stvari. ${ }^{22}$ Teorija ističe kako je upravo naslovljavanjem čl. 13. ZUP-a „Načelo zaštite stečenih prava stranaka“ zakonodavac naglasio kako se pravomoćnost treba promatrati u sklopu načela zaštite stečenih prava stranaka načela koje u praksi Europskog suda pravde ulazi u sadržaj načela pravne sigurnosti kao općeg načela kojem sud pruža zaštitu. ${ }^{23}$

16 O upravnopravnom odnosu v. više u: Borković, op. cit. (bilj, 12), str. 61-65.

17 V. čl. 40. st. 1., čl. 42. kao i čl. 43. ZUP-a.

18 „U upravnim stvarima postupa se što je moguće jednostavnije, bez odgode i uz što manje troškova, ali tako da se utvrde sve činjenice i okolnosti bitne za rješavanje o upravnoj stvari“" (čl. 10. ZUP-a).

19 „Odluka javnopravnog tijela protiv koje se ne može izjaviti žalba niti pokrenuti upravni spor (pravomoćna odluka), a kojom je stranka stekla određeno pravo odnosno kojom su stranci određene neke obveze, može se poništiti, ukinuti ili izmijeniti samo u slučajevima propisanim zakonom“ (čl. 13 ZUP-a).

${ }^{20}$ „U postupku treba utvrditi pravo stanje stvari i u tu se svrhu moraju utvrditi sve činjenice i okolnosti koje su bitne za zakonito i pravilno rješavanje upravne stvari.." (čl. 8. ZUP-a).

${ }_{21}$ O načelu učinkovitosti i ekonomičnosti v. opširnije u: Đerđa, Dario, Opći upravni postupak u Republici Hrvatskoj, Inženjerski biro, Zagreb, 2010., str. 52-54.

22 V. Ibid., str. 58. i 59.

${ }^{23}$ V. o navedenom u: Medvedović, Dragan, „Bitne razlike novog Zakona o općem upravnom postupku prema prijašnjem Zakonu o općem upravnom postupku“, u: Primjena Zakona o općem upravnom postupku, Novi informator, Zagreb, 2010., str. 30. i Šikić, Marko, „Zaštita pravne sigurnosti stranaka u upravnom postupku“, Zbornik Pravnog fakulteta Sveučilišta u Rijeci, 1(2014.), str. 154. 
Dr. sc. Nataša Žunić-Kovačević i dr. sc. Marko Šikić: Upravnopravni pojam zastare s posebnim... Zbornik radova Pravnog fakulteta u Splitu, god. 55, 1/2018., str. 231.- 250.

Nadalje, naglašava se kako se promatranjem pravomoćnosti u sklopu načela zaštite stečenih prava stranaka pojašnjava i bit upravnopostupovnog pojma pravomoćnosti, a to je neopozivost odluke tijela javne uprave, odnosno dopustivost opoziva samo u slučajevima dopuštenima zakonom. Ističe se, što je od naročite važnosti, kako u upravnim postupcima, koji su u najvećem broju slučajeva jednostranački te se najčešće pokreću po službenoj dužnosti, nije najvažnije spriječiti stranke da ponovno započnu postupke u istom predmetu (ne bis in idem), već je primarno potrebno zaštititi stranke od opozivanja akata od strane tijela javne uprave koje su takve akte donijeli (res iudicata). ${ }^{24}$

Smatramo da je institut zastare u upravnom pravu potrebno promatrati uzimajući u obzir kako osnovna obilježja samog instituta zastare, tako i navedene posebnosti upravnog prava i upravnog postupka.

Tako je činjenica nadređene pozicije javnopravnog tijela odnosno podređene pozicije ostalih sudionika u upravnopravnom odnosu vrlo važna i za institut zastare. Subjekti takvih odnosa, naime, ne zaključuju pravne poslove te se dogovaraju o međusobnim pravima i obvezama kako to čine subjekti privatnopravnih odnosa. Javnopravno tijelo u tom odnosu upravne postupke vrlo često pokreće po službenoj dužnosti, uglavnom kako bi građanima nametnulo određene zakonske obveze, kada su ispunjene za to potrebne pretpostavke. Dakako, navedena okolnost upućuje i na to da javnopravno tijelo nema samo pravo već i obvezu pokrenuti upravne postupke te da ono to čini kako bi zaštitilo javni interes. Smatramo kako se navedena pozicija snažno očituje i u institutu zastare - javnopravno tijelo na njezin nastup mora paziti po službenoj dužnosti upravo zbog toga što mu je to dužnost i što na taj način štiti javni interes.

Nadalje, mislimo da se pravna činjenica na kojoj se temelji institut zastare protek vremena, u upravnom pravu mora promatrati upravo iz aspekta navedenih načela učinkovitosti i ekonomičnosti i zaštite stečenih prava stranaka.

Kako smo to ranije u radu i naznačili, načelo učinkovitosti i ekonomičnosti generalno zahtijeva od tijela javne uprave da postupke rješavaju što brže i uz što manje troškova, ali tako da ne povrijede načelo materijalne istine. Kako bi se navedeno načelo moglo ostvariti, u brojnim zakonima koji se primjenjuju u grani upravnog prava propisani su razni rokovi koji vežu i javnopravna tijela i stranke te je osigurana pravna zaštita od šutnje uprave. ${ }^{25}$

Smatramo kako i institut zastare treba promatrati u svjetlu navedenih odredbi i instituta i kako je njegova osnovna svrha, kada ga promatramo kao normativni zahtjev upućen javnopravnim tijelima, upravo podupiranje načela učinkovitosti i ekonomičnosti u radu javne uprave. Dakle, propisivanjem zastare u grani upravnog prava nastoji se postupke pred tijelima javne uprave staviti u čvrste zakonske rokove

24 V. Šikić, Marko, Ofak, Lana, „Nova načela upravnog postupka (s posebnim naglaskom na razmjernost, legitimna očekivanja i stečena prava)“, Zbornik Pravnog fakulteta Sveučilišta u Rijeci, 1(2011.), str. 138. i 139. i Šikić, op. cit. (bilj. 23.), str. 154.

25 Pravna zaštita od šutnje uprave uređena je u ZUP-u čl. 101. i 102. 
i tijela javne uprave disciplinirati te na taj način postići učinkovitost i ekonomičnost upravnih postupaka.

$\mathrm{S}$ druge strane, kad zastaru promatramo iz aspekta građana - stranaka u postupcima, držimo da zastara ima za cilj primarno zaštitu pravne sigurnosti tj. onemogućavanje javnoj vlasti da nakon proteka zakonom određenih rokova građanima nameće (zastarjele) obveze. Na navedeni se način realizira načelo zaštite stečenih prava stranaka, odnosno onaj dio navedenog načela koji zabranjuje diranje u pravomoćne akte kojima su građanima određene obveze. Prema tome, i institut zastare i institut pravomoćnosti uzimaju u obzir utjecaj proteka vremena na pravne odnose $-\mathrm{s}$ tom razlikom da pravomoćnost polazi od svojevrsnog ,postupovnog vremena" tj. od strankinog iskorištavanja pravnog puta i pravnih lijekova, dok zastara uzima u obzir realno, sunčevo vrijeme koje je određeno normiranjem čvrstih zakonskih rokova.

\section{ZASTARA U POREZNOM PRAVU - UVODNO O POJMU I ZNAČENJU INSTITUTA}

U nastavku rada naša ranija zapažanja i zaključke vezane uz institut zastare i posebne značajke zastare u upravnom pravu dodatno ćemo razraditi i pojasniti kako bismo se približili pojmu zastare u poreznom pravu.

Nastanak, promjenu i prestanak prava vezujemo uz pravni odnos koji nastaje suglasnošću volja sudionika odnosa, ljudskom radnjom, prirodnim događajem kao i brojnim drugim činjenicama. Takve činjenice koje dovode do stvaranja, promjene ili prestanka nekog prava i pravnog odnosa zovemo pravnim činjenicama. Pravna činjenica na kojoj se temelji pravni institut zastare jest protek vremena. Zakonska norma propisuje učinak i posljedice nastupa svake pravne činjenice. Kako smo ranije u radu i istaknuli, još je u rimsko doba vrijedilo shvaćanje da s ostvarenjem subjektivnih prava ne treba nepotrebno odugovlačiti. Zakonsko ograničenje vremena u kojemu se vjerovniku jamči sudska zaštita izraz je takvog shvaćanja. Svrha je instituta zastare pridonijeti ostvarenju pravne sigurnosti i sprečavanje stanja trajne pravne tj. sudske zaštite. ${ }^{26}$ Naime, pravni poredak i pravna sigurnost ne trpe postojanje jednog trajnog pravnog stanja u kojemu se prava ne ostvaruju i obveze ne izvršavaju i stoga se i vrijeme pravne zaštite ograničava zakonom. U nekim se slučajevima gasi i samo pravo.

Objektivno pravo postavlja granice subjektivnim pravima, posebice u općem interesu i interesu društva. Svako izvršavanje subjektivnog prava koje je protivno njegovu cilju ili svrsi nije pokriveno njegovim sadržajem. Korektivi koji sužavaju

26 Vidi, tako, Horvat, L., „Posljedice zastare u porezno-pravnom odnosu“, Zbornik radova znanstvenog skupa „Hrvatska pred vratima EU - fiskalni aspekti“, HAZU, Zagreb, 2005., str. 309-315. 
Dr. sc. Nataša Žunić-Kovačević i dr. sc. Marko Šikić: Upravnopravni pojam zastare s posebnim... Zbornik radova Pravnog fakulteta u Splitu, god. 55, 1/2018., str. 231.- 250.

granice subjektivnih prava su brojni. ${ }^{27}$ Ovisno o naravi ili vrsti prava ${ }^{28}$ i rješenjima konkretnog pravnog poretka, nevršenje prava ili vršenje prava na određeni način protekom određenog vremena dovode do različitih posljedica za titulara tog prava, poput nastanka ili pak prestanka ili gubitka prava. ${ }^{29}$

Zastara kao posljedica nevršenja prava kroz zakonom određeno vrijeme može imati različite učinke. U teoriji nalazimo različita, a dva su temeljna, pravna stajališta glede posljedica izazvanih nastupom zastare. Prema prvom stajalištu, vjerovnik zadržava subjektivno pravo u materijalnom smislu te gubi „samo“ pravo na sudsku zaštitu ili na tužbeni zahtjev. Dakle, vjerovnik gubi samo dio svoga prava i to dio koji se sastoji u zakonskoj i sudskoj mogućnosti ostvarenja istog. Ovakvo stajalište se odnosi na privatnopravne grane, prvenstveno na obvezno pravo. Prema drugom stajalištu, nastupom zastare prestaje postojati vjerovnikovo subjektivno pravo. Ovakvo stajalište vezujemo uz javno pravo, poput poreznog prava. Jasno, navedena stajališta imaju zaseban nomotehnički izričaj.

Nastavno na gore navedene razlike, ovisno o vrsti ili naravi prava, valja reći da u privatnom pravu nastupom zastare prestaje pravna obveza dužnika, s obzirom na to da je postala neutuživa i postaje tj. pretvara se u naturalnu obvezu. Budući da se subjektivno pravo sastoji od vjerovnikova ovlaštenja da se njime koristi ili ne koristi kao i od prava na sudsku zaštitu, može se zaključiti da u privatnom pravu nastupom zastare vjerovnik nije izgubio ovlaštenje koje čini sadržaj njegova subjektivnog prava. Prema tome, dužnik svoju obvezu može izvršiti a vjerovnik može primiti ispunjenje. Ako dužnik izvrši zastarjelu obvezu, nema pravo na povrat jer je njegovo ovlaštenje bilo istaknuti prigovor zastare čime bi se oslobodio pravne obveze. Prigovor zastare dužnik će moći staviti u sudskom postupku koji je vjerovnik pokrenuo radi izvršenja pravne obveze. Ako dužnik ne iskoristi takvo svoje ovlaštenje, sud će presuditi u korist vjerovnika jer se u privatnom pravu o zastari ne vodi računa po službenoj dužnosti.

27 Uz teoriju zloupotrebe prava te zabranu zloupotrebe prava koja iz nje proizlazi i vrijedi prvenstveno u građanskom pravu, korektiv vršenja subjektivnih prava u oba područja - građanskog prava i poreznoga prava - jest načelo poštenja i savjesnosti. Vidi, detaljnije u Žunić Kovačević, N., ,Zastara - o primjeni građansko-pravnih pravila u poreznom pravu i sudska praksa“, Zbornik Pravnog fakulteta Sveučilišta u Rijeci, 1(2009.).

28 Subjektivna se prava izvršavaju poduzimanjem svih radnji i postupaka na koje je titular ovlašten, a ovisno o vrsti i naravi subjektivnog prava. Stvarna se prava izvršavaju korištenjem, stvarnim i pravnim raspolaganjem sa stvarima. Obvezna se prava u pravilu izvršavaju zahtijevanjem i primanjem činidbe, kao i drugim radnjama poput kompenzacije, poduzimanja ovršnih mjera i sl. Izvršavanjem ili vršenjem subjektivnih prava, ona se ostvaruju ili realiziraju. Apsolutna prava, posebice stvarna, i pored akata vršenja prava i dalje traju. No, obvezna prava, uključujući dakle imovinska prava, vršenjem se iscrpljuju odnosno prestaju. Iako pravni poredak ne prisiljava titulara na vršenje prava, nevršenje nekih vrsta prava može imati za titulara štetne posljedice. V., opširnije, Krneta, S., Odabrane teme privatnog prava, Pravni fakultet Univerziteta Sarajevo, 2007., str. 76-78.

29 Važno je istaknuti stajalište teorije gdje se kod nekih subjektivnih prava govori i o obvezi na njihovo vršenje ili izvršavanje. O obvezi vršenja subjektivnih prava govori se stoga što ona proizlazi iz općeg interesa. Takvu obvezu mogli bismo, barem teoretski, navesti i kod subjektivnog prava poreznih tijela. Štetna posljedica koja treba pogoditi titulara - porezno tijelo - zbog nevršenja prava jest prestanak samog prava. No, zbog propuštanja obveze na vršenje svoga prava moglo bi se u nekim slučajevima čak govoriti i odgovornosti za naknadu štete. Tako, Krneta, str. 78. Prema, Zunić Kovačević, loc. cit. 
Dr. sc. Nataša Žunić-Kovačević i dr. sc. Marko Šikić: Upravnopravni pojam zastare s posebnim... Zbornik radova Pravnog fakulteta u Splitu, god. 55, 1/2018., str. 231.- 250.

Kada je riječ o drugoj vrsti prava, javnom pravu, tada je situacija drugačija. Razlika je uvjetovana, između ostaloga, u pravnim osnovama pravnih odnosa na čemu počiva razlikovanje javnoga i privatnoga prava. ${ }^{30}$

Bitno je obilježje porezno-pravnog odnosa hijerarhija, neravnopravnost i nadređenost odnosno podređenost jednog sudionika drugom. Subjekti poreznopravnog odnosa ne zaključuju pravni posao i ne dogovaraju se o sadržaju međusobnih odnosa kao što je to slučaj kod privatnopravnih odnosa. Poreznopravni odnos nastaje kada su ispunjeni uvjeti propisani zakonom. ${ }^{31}$ Porezno tijelo nema samo pravo već obvezu utvrditi poreznu obvezu, zatim ako postoji, i porezni dug. Subjektivno pravo poreznog tijela, najčešće vjerovnika u poreznopravnom odnosu u ovom se slučaju ne sastoji od vjerovnikova ovlaštenja da se njime koristi ili ne koristi kao i od prava na sudsku zaštitu. Porezno tijelo kao javnopravna strana u poreznopravnom odnosu ima obvezu izvršavati subjektivno pravo te nastupom zastare gubi i taj dio prava ovlaštenje koristiti se njime.

30 U privatnom su pravu sudionici odnosa, u pravilu, ravnopravni dok takvog obilježja odnosa u javnom pravu nema.

31 Hrvatska i inozemna, stručna i znanstvena, literatura u prošlosti pa do danas zauzima različita stajališta u odgovoru na pitanje što se ima smatrati pravnom osnovom i izvorom obveze građana na plaćanje poreza: je li to zakon ili pak odluka, porezni akt, rješenje javnopravnog, poreznog tijela adresat koje je porezni obveznik. Iako odgovor na to pitanje nije u fokusu moderne porezne literature, ima značajnu ulogu u razmatranju instituta zastare. Ova teorijska razlika ima i značajnu ulogu u oblikovanju prirode suđenja u poreznim stvarima i ovlasti suca u odlučivanju. Ako se smatra da je druga pozicija dominantna, tada bi sudska kontrola poreznog postupanja bila vrsta pravosudne revizije kakva je trenutačno namijenjena sudovima, primjerice, u common law zemljama. Sudac je u ovom slučaju pozvan ili potvrditi odluku poreznog tijela ili, alternativno, poništiti je. S druge strane, ako se prvo navedeno stajalište zauzme, upravni sudac bi imao ovlasti za promjenu odluke, praktički izmjenjujući bilo koji njezin dio u onoj mjeri u kojoj je u skladu s relevantnim poreznim zakonom. Dakle, sudac tada utvrđuje i poreznu obvezu, dužnost plaćanja poreza, računajući točan iznos, i sl., praktički zamjenjuje i poreznu prijavu poreznog obveznika i porezno rješenje poreznog tijela. Obveza plaćanja poreza nametnuta je poreznim obveznicima zakonom, a ne nalogom ili odlukom javnopravnog, poreznog tijela pa porezno rješenje nije akt konstitutivne već deklaratorne naravi. Porezno tijelo nema diskrecijske ovlasti u poreznom postupku niti može slobodno raspolagati i pregovarati o kojem bitnom elementu porezne obveze koja se utvrđuje. Drugim riječima, u oporezivanju jedino u poreznom sporu porezni/upravni sudac može ići i mimo zahtjeva poreznog tijela i poreznog obveznika u utvrđenju porezne obveze i poreznog duga, postupajući u skladu s poreznim zakonima. Tako, Greggi, M., Žunić Kovačević, N., „Lights and Shadows on the Implementation of the Alternative Dispute Resolution (ADR) system in the Italian and Croatian Tax Trial", Zbornik Pravnog fakulteta Sveučilišta u Rijeci (1991.), v. 38, br. 1, 377-396 (2017.), str. 380-381, i dr.; Tako, vidi, Selicato, P., L'attuazione del tributo nel procedimento amministrativo, Milan, Giuffrè, 2014. 


\section{ZASTARA U HRVATSKOM POREZNOM PRAVU I RJEŠENJA POREZNE REFORME IZ 2017.}

\section{Historijat nastanka i izmjena instituta porezne zastare}

U poreznom je pravu pitanje zastare danas uređeno Općim poreznim zakonom. ${ }^{32}$ Do donošenja prvog takvog općeg zakona - Općeg poreznog zakona 2001. ${ }^{33}$ institut je zastare u području poreznog prava bio reguliran Zakonom o porezu na dohodak. ${ }^{34}$ Institut zastare potraživanja porezne obveze bio je reguliran odredbama članaka od 100. do 102. Relativni je rok zastare iznosio pet godina, dok je apsolutna zastara nastupala nakon isteka deset godina.

Prvi, OPZ 2001. donesen je 2000. i do donošenja novoga zakona 2008. mijenjan je u svega dva navrata, ${ }^{35} \mathrm{i}$ to u pitanjima pretežito tehničke naravi. Prvi, OPZ 2001. ocijenjen je u svakom pogledu pozitivno, no među primjedbama svakako je bila ona koja se odnosila na duljinu zastarnih rokova. Naime, skraćivanju se zastarnih rokova mogu opravdano i danas uputiti prigovori. ${ }^{36}$

OPZ 2008, ${ }^{37}$ mijenjan u više navrata. Izmjenama iz 2011. ${ }^{38}$ uređuje se prvi put zastoj zastare, propisujući da zastara ne teče ako se radi naplate poreza, kamata i troškova ovrhe vodi postupak pred sudom, za vrijeme trajanja tog postupka. ${ }^{39}$ Tada je dodatno uređeno pitanje zastare prava poreznog tijela na naplatu pa je stavak 8. predmetnog članka (94.) promijenjen uređujući da se po nastupu zastare porezno tijelo čija je tražbina osigurana zalogom ili hipotekom može namiriti samo iz opterećene stvari ako je drži u neposrednom posjedu ili ako je njegovo pravo upisano u javnoj knjizi te da se zastarjela tražbina po osnovi kamata ne može namiriti ni iz opterećene stvari. Prve izmjene iz 2012. značile su, pored ostaloga, najavljeno uvođenje financijske discipline s probojem pravne osobnosti trgovačkih

32 Opći porezni zakon, NN 115/16, stupio na snagu 1. siječnja 2017. (dalje u tekstu: OPZ 2017).

33 Prvi, Opći porezni zakon, NN 127/2000, 86/2001, 150/2002 (dalje u tekstu: OPZ 2001) te Opći porezni zakon, NN 147/2008, 18/2011, 78/2012, 136/2012, 73/2013, 26/2015, 44/2016, 115/2016 (dalje u tekstu: OPZ 2008).

34 NN 109/93., 95/94., 25/95. - pročišćeni tekst, 52/95 (ispr.), 106/96. i 164/98.

35 NN 86/2001. i 150/2002.

36 Na žalost, OPZ 2008., a ni 2017. nije išao u smjeru produženja zastarnih rokova. Detaljnije o uređenju zastare u poreznom pravu do 2001. godine, tj. do donošenja starog OPZ-a, vidi, Vukić, Nikola, „Zastara potraživanja poreza u Republici Hrvatskoj“, Tendencije u razvoju financijske aktivnosti države, Zbornik radova sa Znanstvenog skupa povodom 100. obljetnice tiskanja knjige Stjepana Posilovića „Financijalna znanost“, HAZU, Zagreb, 2000., str. 309-323. Vidi, i o reformi 2017.

37 NN 147/2008.

38 NN 18/2011.

39 Bio je to novi stavak 7. u članku 94. 
Dr. sc. Nataša Žunić-Kovačević i dr. sc. Marko Šikić: Upravnopravni pojam zastare s posebnim... Zbornik radova Pravnog fakulteta u Splitu, god. 55, 1/2018., str. 231.- 250.

društava za porezni dug po posebnom postupku dokazivanja zlouporabe i manjkavim nomotehničkim rješenjima zastare u tim postupcima. ${ }^{40}$

Do zadnjih izmjena, iz 2017. godine, moguće je pratiti razvoj instituta zastare kroz prizmu promjena zakonskog okvira te kroz sudsku praksu. Ipak, moguće je primijetiti da navedeni razvoj u hrvatskom poreznom pravu nije toliko evidentan kroz izmjene normativna okvira. Drugim riječima, dinamici promjena instituta zastare kontinuirano su doprinosila postupanja poreznih tijela te upravno sudovanje gdje se kristalizira nekoliko pitanja s neujednačenim ili nejasnim upravnim i sudskim stajalištima i praksama.

Odgovore na najveći dio pitanja dobili smo zadnjom poreznom reformom i novim OPZ-om 2017., koje kratko prikazujemo kroz prikaz važećih normi i neujednačene upravne i sudske prakse nastale na temelju OPZ-a 2001. i OPZ-a 2008. koja je jednim dijelom bila povod posljednjim zakonskim intervencijama u predmetni institut.

\section{Prikaz izmijenjenih odredbi novog OPZ-a o zastari i okolnosti koje su bile povod promjenama}

Praksa primjene instituta zastare iznjedrila je nekoliko pitanja koja su izazivala dvojbe: pitanje prestanka prava poreznog tijela nastupom zastare te posljedično prestaje li obveza poreznog obveznika ili ostaje kao naturalna obveza; drugo, pitanje svrhe i učinka apsolutnog i relativnog roka zastare; treće, pitanje duljine zastarnih rokova i njihove naravi odnosno je li zastarni rok subjektivan ili objektivan ${ }^{41}$ i posljednje, ne manje važno, jest i pitanje primjene građanskopravnih normi u kontekstu poreznog postupka koje je potvrđeno kroz različita stajališta glede pitanja je li porezni dužnik plaćanjem zastarjele obveze platio dug ili nedug, odnosno ima li pravo na povrat plaćenog zastarjelog duga. Te dvojbe potvrđuju i različita stajališta u odnosu na pitanje treba li na zastaru u poreznim stvarima paziti po službenoj dužnosti ili samo po prigovoru, pa s obzirom na specifičnost poreznog odnosa spram privatnopravnih ugovornih odnosa, u ocjenjivanje zakonitosti rješenja poreznih

40 Izmjene u NN 78/2012., 136/2012. i 73/2013. (implementacija Direktiva o administrativnoj suradnji i razmjena informacija između država članica Europske unije o isplaćenim kamatama na dohodak od štednje. Izmjenama objavljenima u NN 26/2015. konačno su obvezujuća mišljenja (engl. advance tax rullings) uvedena u hrvatski porezni sustav. Tada se i uređuju kroz nove odredbe o upravnom ugovoru i poreznoj nagodbi navedene posebne vrste poreznih akata. Posljednja, izmjena tijekom 2016., u NN 44/2016., propisuje nove odredbe o obveznoj automatskoj razmjeni informacija o financijskim računima.

${ }^{41}$ U opisanom kontekstu teško je pronaći uvjerljive argumente u korist subjektivnog tumačenja porezne zastare odnosno ne može se naći osnova za shvaćanje zastarnog roka kako je bio propisan do zadnjih izmjena, a napose u važećim odredbama o zastarnom roku kao subjektivnom roku. Uvođenje subjektivnog elementa u pojam porezne zastare odnosno shvaćanje da je riječ o subjektivnom roku pristup je koji je ugrozio pravnu sigurnost i zakonitost oporezivanja, o čemu se očitovao Europski sud u nekoliko svojih presuda. Nema sumnje da je ranije, a posebno u današnje vrijeme, takvo tumačenje štetno te da bi se moglo veoma negativno odraziti na supra opisane napore zakonodavca u promicanju nove paradigme poreznopravnog odnosa, poglavito u smislu moralne dimenzije (ne)izvršavanja poreznih obveza. No, produljenje zastarnog roka, pa čak ukidanje zastare za utaju poreza, normativna su rješenja poredbenih zakonodavstava i opravdano sredstvo svake vlasti, pod pretpostavkom da su kao takvi propisani. 
Dr. sc. Nataša Žunić-Kovačević i dr. sc. Marko Šikić: Upravnopravni pojam zastare s posebnim... Zbornik radova Pravnog fakulteta u Splitu, god. 55, 1/2018., str. 231.- 250.

tijela spada i razmatranje je li rješenje doneseno nakon proteka zastarnih rokova zakonito. Intrigantno pitanje zastare propitivalo se na akademskoj, ali i na stručnoj razini u zadnjem desetljeću, pa su navedena pitanja donekle rasvijetljena ne samo kroz prakse poreznih tijela, sudsku praksu, već i znanstvene i stručne radove. ${ }^{42}$

\section{Pitanje početka tijeka zastare ili pitanje naravi poreznog zastarnog roka kod zastare prava na utvrđivanje poreza}

Praksa poreznih i sudbenih tijela pokazala je dvojbe oko tumačenja naravi zastarnog roka. Naime, OPZ 2001. propisao je početak tijeka zastare prava na utvrđivanje poreza i kamata na način da zastara prava na utvrđivanje porezne obveze i kamata počinje teći nakon isteka godine u kojoj je trebalo utvrditi porezne obveze. Jednako je propisivao OPZ 2008. Praksa je upravnih tijela pokazala da se ovako propisan početak tijeka zastare tumači na način da zastara počinje teći od trenutka kada je porezno tijelo moglo utvrditi poreznu obvezu i kamata, odnosno od trenutka saznanja za nastanak porezne obveze. Slična se stajališta zauzimaju i u sudskoj praksi.

Tako je na sjednici svih sudaca i sudskih savjetnika 5. studenoga 2001. Upravni sud RH donio zaključak: „Za utvrđivanje apsolutnog roka zastare prava poreznog tijela na utvrdivanje porezne obveze mjerodavno je kada je porezno tijelo saznalo za poreznu obvezu." ${ }^{43} \mathrm{U}$ više presuda istoga suda ostalo se pri istom stajalištu, no praksa bilježi i drugačija stajališta pa je to i slučaj s presudom Visokog upravnog suda od 17. lipnja 2015., gdje je zauzeto stajalište da trenutak saznanja poreznog tijela za poreznu obvezu nije mjerodavan za početak tijeka roka zastare. Ipak, Visoki upravni sud naknadno donosi zaključak sjednice svih sudaca 2016. kojim se „(...) ostaje kod zaključka sjednice sudaca Upravnog suda Republike Hrvatske od 5. studenoga 2001." ${ }^{44}$ Dodatno se istim zaključkom utvrđuje stajalište o utjecaju saznanja poreznog tijela za poreznu obvezu (u postupku utvrđivanja poreza na dohodak) pa je donesen zaključak sukladno kojemu je za ,,... utvrđivanje zastare prava poreznog tijela na utvrđivanje obveze predujma poreza na dohodak od imovine i imovinskih prava mjerodavno kada je porezno tijelo saznalo za poreznu obvezu. “45 Dakle, iznenađujuće, Visoki upravni sud vraća se na ranije zauzeto stajalište iz 2001. kojim se zastarni rok tumači kao subjektivni rok. Budući da

42 V. posebno radove sudaca Visokog upravnog suda (Upravnog suda RH), npr. Juričić, Mirjana, „Zastara u poreznim stvarima“, Upravno pravo - aktualnosti upravnog sudovanja $i$ upravne prakse, 2008, Inženjerski biro; Kriletić, Marija, „Zastara naplate carine i prekršajnog progona u praksi Upravnog suda Republike Hrvatske“, Upravno pravo - aktualnosti upravnog sudovanja i upravne prakse, 2008. Inženjerski biro; Rostaš-Beroš, Lidija, „Porezna zastara u praksi upravnih sudova“, Novosti u upravnom pravu i upravno-sudskoj praksi, Savjetovanje 2013., Narodne novine. V. i, Bassegli Gozze, Vlaho, „Institut zastare u hrvatskom poreznom pravu - dugogodišnja otvorena pitanja i mogući odgovori na njih“", Sveske za javno pravo, Fondacija Centar za javno parvo, br. 8., 2017., i dr.

43 Su-151/2001-3, 5 ( ZSS-5/2001): IV. 2017.).

44 Stajalište dostupno na http://www.upravnisudrh.hr/frames.php?right=odluke.html. (10. IX.

45 Loc. cit. 
je svrha uređenja pravnog instituta zastare stvoriti izvjesnost i pravnu sigurnost, takvo tumačenje norme iznenađuje jer norma po svojem sadržaju i obliku to i ne traži - jer ne govori o trenutku od kada je porezno tijelo saznalo, već o trenutku kada je porezno tijelo trebalo utvrditi poreznu obvezu. Jasno pretvaranje zakonom propisanog objektivnog zastarnog roka u protumačeni, subjektivni zastarni rok protivan je svrsi i cilju instituta zastare i normi kojom je uređen. ${ }^{46}$ Pravna sigurnost i ostvarenje načela zakonitosti u cilju ostvarenja pravne države traže da uz svaki subjektivni rok zakon jasno propiše i objektivni rok. U prilog tome govori presuda Europskog suda C-52/14 od 11. lipnja 2015. u kojoj je raspravljano pitanje može li tijek dvostrukog roka zastare ovisiti o saznanju tijela o relevantnim nepravilnostima te je zaključeno da rok počinje teći računajući od dana prestanka te nepravilnosti, dakle neovisno o datumu saznanja za relevantne nepravilnosti. ${ }^{47}$

Navedene su dvojbe konačno otklonjene na način da OPZ 2017. u članku 108., stavku 2., jasno propisuje rok zastare prava na utvrđivanje poreza i kamata kao objektivan rok jer zastara prava na utvrđivanje porezne obveze i kamata počinje teći istekom godine u kojoj je nastala porezna obveza pri čemu je nastanak porezne obveze uvijek propisan posebnim poreznim zakonima. Isti je neovisan o subjektivnim momentima i saznanjima, ne samo poreznog tijela već i poreznog obveznika.

\section{Primjena privatnopravnih odredbi u poreznom pravu i pretvaranje zakonske porezne obveze u naturalnu ili moralnu obvezu}

Odredbe OPZ 2001. i OPZ 2008. gotovo su istovjetne u pitanjima uređenja porezne zastare (v. amplius supra) pa jednako sadrže odredbu koja upućuje na supsidijarnu primjenu odredbi privatnoga prava, odnosno Zakona o obveznim odnosima na način da se Zakon o obveznim odnosima primjenjuje na poreznu zastaru ako odredbama OPZ-a nije drukčije propisano. ${ }^{48}$ Takva je odredba bila temelj brojnih zaključaka i praksi poreznih tijela o nužnosti prigovora poreznog obveznika na zastaru, jer u protivnom porezna tijela nisu pazila na isto po službenoj dužnosti. Ipak, istim je zakonima, OPZ-om 2001. i OPZ-om 2008., i bilo drukčije propisano pa u tom pitanju nije bilo mjesta za supsidijarnu primjenu normi privatnog prava. Naime, kada je riječ o pravima poreznog tijela koja zastarijevaju, ona su zakonom jasno i detaljno uređena predmetnim zakonima. Isti zakoni svojim su odredbama precizno uredili načelo zakonitosti postupanja poreznih tijela. Tako su oba zakona propisivala da je porezno tijelo dužno zakonito utvrđivati sva prava i obveze iz poreznopravnog odnosa. Dodatno je bilo propisano da je porezno tijelo dužno upozoriti sudionike poreznopravnog postupka na njihova prava i obveze dok je porezno tijelo dužno utvrđivati sve činjenice koje su bitne za donošenje

46 Takvim tumačenjem moguće je da zapravo zastara nikada i ne nastupi.

47 Vidi presudu, Zahtjev za prethodnu odluku i presudu na http://eur-lex.europa.eu/legal-content/HR/ TXT/PDF/?uri=OJ:C:2014:142:FULL\&from=IT (13. IX. 2017.).

48 Članak 90., stavak 6. OPZ 2000; Članak 94., stavak 12 OPZ 2008. 
Dr. sc. Nataša Žunić-Kovačević i dr. sc. Marko Šikić: Upravnopravni pojam zastare s posebnim... Zbornik radova Pravnog fakulteta u Splitu, god. 55, 1/2018., str. 231.- 250.

zakonite i pravilne odluke, pri čemu je dužno s jednakom pažnjom utvrditi i one činjenice koje idu u prilog poreznog obveznika.$^{49}$ Stajalište pravne teorije potvrđuje da je supsidijarna primjena privatnopravnih normi u poreznim stvarima gotovo suprotna pravnoj naravi poreznog prava jer je riječ o koncepcijski suprotstavljenim pristupima.$^{50} \mathrm{No}$, pogrešno je temeljem navedenoga zaključiti da nema međusobnog utjecaja i povezanosti privatnoga i javnoga prava. ${ }^{51}$

Praksa primjene navedene, upućujuće, odredbe na supsidijarnu primjenu Zakona o obveznim odnosim temeljila se na stajalištu da se važeći propis treba primjenjivati u potpunosti. Tako je Visoki upravni sud u više navrata zauzimao stajalište da niti sud, niti porezna tijela ne trebaju paziti na zastaru po službenoj dužnosti već samo po prigovoru stranke. ${ }^{52}$ Ipak, prvostupanjski su upravni sudovi u praksi zauzimali i drugačije stajalište i utvrđivali nastup zastare. ${ }^{53}$ Posebno ističemo i stajalište Visokog upravnog suda prema kojem sud ne može odlučivati o prigovoru zastare istaknutom tek u tužbi, s obzirom na to da prigovor koji nije bio predmetom upravnog postupka ne može biti predmetom upravnog spora.

Konačno je na sjednici Financijsko-radnopravnog i imovinskopravnog odjela održanoj 2014., donesen zaključak: „Porezna tijela u poreznom postupku na zastaru paze po službenoj dužnosti." ${ }^{4}$ S Štoviše, Vrhovni sud Republike Hrvatske presudom iz 2014. godine potvrđuje navedeno određujući da je Ministarstvo financija, Samostalna služba za drugostupanjski upravni postupak „(...) dužno po službenoj dužnosti paziti na bitne povrede odredaba postupka, pravilnu primjenu materijalnog prava i pravilnost i potpunost činjeničnog stanja, što znači da je u konkretnoj situaciji bilo dužnost ispitati je li nastupila zastara prava na utvrđivanje porezne obveze.(...) "..55

49 V. OPZ 2001. i OPZ 2008., dio: Načela oporezivanja.

50 Tako, Žunić Kovačević, loc. cit; Arbutina, Hrvoje, „Mišljenje u predmetu obveza tijela javne vlasti i upravnih sudova na vođenje račna o nastupu zastare u poreznopravim predmetima“, prema, Jenjić, Jasminka, Orlić Zaninović Senka, Posebnosti upravnog postupka u poreznim stvarima, Pravosudna akademija, Zagreb, 2016., str. 54.

${ }_{51}$ Normiranje načela postupanja u dobroj vjeri, prividnih pravnih poslova ili pak zlouporabe prava pokazatelji su utjecaja privatnoga prava na porezno pravo jer se instituti nastali u privatnom pravu preuzimaju u javno pravo. To zahtijeva posebna znanja i spretnost kreatora zakona, a moguća su dva temeljna pristupa u tome jer zahtjev pravne sigurnost traži: ili cjelovito preuzimanje instituta privatnog prava u javno pravo gdje norma javnog prava upućuje na primjenu normi pozitivnog prava u cijelosti, ili cjelovito i posebno uređenje privatnopravnog instituta u javnopravnom kontekstu, bez upućivanja na primjenu normi privatnog prava. Drugim rječima, djelomično uređenje instituta na način da se stvara kakav "mješoviti" institut javnog i privatnog prava predstavlja ugrozu pravne sigurnosti. V. Žunić Kovačević, op. cit. (bilj. 28), str. 684, 685 i dr.; V. više o tome, Vanistendeal, F., „Legal Framework for Taxation“ u: Tax Law Design and Drafting, Vol I, ed. By Victor Thuronyi, IMF, Washington, D. C. 1996.; Gordon K., Richard, „Law of Tax Administration and Procedure“ u: Tax Law Design and Drafting, Vol I, ed. By Victor Thuronyi, IMF, Washington, D. C. 1996.

52 Vidi, Jenjić, Orlić Zaninović, op. cit. (bilj. 50), str. 56.

53 Ibid., str. 57.

${ }^{54}$ Stajalište dostupno na http://www.upravnisudrh.hr/frames.php?right=odluke.html. (10. IX. 2017.). V. i Jenjić, Orlić Zaninović, op. cit. (bilj. 50), str. 53.

55 Presuda VSRH, broj: UZZ 31/11-5, dostupno na http://sudskapraksa.vsrh.hr/supra/OdlukaTekst. asp?doID=38 (12. IX. 2017.). 
Navedeni kontekst iznjedrio je i dvojbena stajališta prisutna u praksi upravnih tijela, ali i sudova prema kojima je porezna obveza utvrđena prvostupanjskim rješenjem. Financijski i radnopravni odjel Visokog Upravnog suda na sjednici iz 2015., vezano uz relativnu zastaru u poreznim stvarima, donio je zaključak: „Ostaje se kod dosadašnje prakse po kojoj se porezna obveza utvrđuje prvostupanjskim poreznim rješenjem. Od donošenja prvostupanjskog poreznog rješenja do donošenja rješenja po žalbi relativna zastara ne teče, već samo apsolutna”. Nešto kasnije, na sjednici Financijskog i radnopravnog odjela, održanoj 2016., zaključak je Visokog upravnog suda: „Drugostupanjsko rješenje kojim je odbijena žalba protiv prvostupanjskog rješenja o utvrđivanju porezne obveze nije nezakonito (samo) zato što je doneseno nakon nastupa apsolutnog roka zastare“. ${ }^{56}$

No, u ranije navedenoj presudi, Vrhovni sud RH jasno utvrđuje da ,učinak na prava i obveze stranaka ima konačno rješenje doneseno u upravnom postupku (upravni akt). Konačnost rješenja znači da je postupak donošenja upravnog akta dovršen. Stoga se, u situaciji kad je protiv prvostupanjskog rješenja dopuštena žalba, ne može smatrati da je već donošenjem prvostupanjskog rješenja konačno odlučeno o pravu i obvezi stranke, jer se tek propuštanjem podnošenja žalbe ili donošenjem rješenja drugostupanjskog tijela povodom žalbe odbacivanjem žalbe, odbijanjem žalbe ili izmjenom rješenja (̌̌l. 239. ZUP-a) dovršava postupak donošenja upravnog akta“ ${ }^{57}$ Dakle, obveza poreznog tijela da po službenoj dužnosti pazi na nastup zastare ne prestaje donošenjem prvostupanjskog poreznog rješenja, a drugostupanjsko tijelo, u okviru svoje dužnosti da ispita zakonitost pobijanog poreznog akta u cijelosti, ne ograničavajući se na žalbene razloge, dužno je po službenoj dužnosti paziti i na zakonitost vlastitog postupanja pa i na eventualni nastup zastare, jednako relativne i apsolutne zastare.

OPZ 2017. konačno rješava navedene dvojbe i vodi k ujednačavanju prakse kada u članku 109. utvrđuje da su na nastup zastare prava na utvrđivanje po službenoj dužnosti dužna paziti prvostupanjska porezna tijela do donošenja i dostave poreznog rješenja. Također, uređuje da su na nastup zastare prava na utvrđivanje po službenoj dužnosti dužna paziti i drugostupanjska tijela do donošenja i dostave rješenja o žalbi. U tim slučajevima, ako tijela utvrde da je nastupila zastara prava na utvrđivanje poreza i kamata, trebaju rješenjem utvrditi nastup zastare i obustaviti postupak. Jednako je važno i uređenje situacije, $\mathrm{u}$ istom članku zakona, kada u upravnom sporu sud poništi porezno rješenje i vrati na ponovno odlučivanje, a u međuvremenu je nastupila zastara prava na utvrđivanje, jer će nadležna porezna tijela tada rješenjem utvrditi nastup zastare i obustaviti postupak.

Kada je riječ o zastari prava na naplatu, tada je dužno na zastaru paziti po službenoj dužnosti prvostupanjsko tijelo do donošenja rješenja i dostave rješenja, a drugostupanjska tijela dužna su po službenoj dužnosti paziti je li u trenutku donošenja prvostupanjskog rješenja nastupila zastara prava na naplatu.

56 Stajalište dostupno na http://www.upravnisudrh.hr/frames.php?right=odluke.html. (12. IX. 2017.).

57 Ibid. 
Dr. sc. Nataša Žunić-Kovačević i dr. sc. Marko Šikić: Upravnopravni pojam zastare s posebnim... Zbornik radova Pravnog fakulteta u Splitu, god. 55, 1/2018., str. 231.- 250.

Zakon utvrđuje, iako se nomotehnički gledano čini suvišnim, da je rješenje o utvrđivanju ili naplati porezne obveze, kamata i troškova ovrhe doneseno nakon nastupa zastare nezakonito te da se porezni dug za koji je utvrđena zastara prava na utvrđivanje ili naplatu porezne obveze, kamata i troškova ovrhe otpisuje iz poreznih evidencija. ${ }^{58}$

Navedeno složeno pitanje upućuje i na dvojbena stajališta o prestanku prava poreznog tijela na naplatu poreza i kamata. U praksi poreznih tijela, ali i sudova, nije bilo ujednačenosti u odgovoru na pitanje gasi li se pravo poreznog tijela zastarom ili je riječ o prestanku tražbine uslijed čega se zakonska obveza poreznog obveznika pretvara u naturalnu obvezu.

Naime, u odredbama o poreznoj zastari OPZ 2001. (članak 90. stavak 1.) i OPZ 2008. (članak 94. stavak 1.) bilo je propisano da pravo poreznog tijela na utvrđivanje porezne obveze i kamata, pokretanje prekršajnog postupka, naplatu poreza, kamata, troškova ovrhe i novčanih kazni, te pravo poreznog obveznika na povrat poreza, kamata, troškova ovrhe i novčanih kazni zastarijeva za tri godine, računajući od dana kada je zastara počela teći.

OPZ 2017., uređujući ista pitanja, propisuje da pravo $i$ obveze poreznog tijela na utvrđivanje porezne obveze i kamata, pravo i obveza poreznog tijela na naplatu poreza, kamata i troškova ovrhe te pravo poreznog obveznika na povrat poreza, kamata i troškova ovrhe zastarijeva za šest godina, računajući od dana kada je zastara počela teći. ${ }^{59}$

Time je zakonodavac pokušao otkloniti dvojbe na način da prestankom prava prestaje $\mathrm{i}$ obveza, te da nema promjene naravi obveze poreznog obveznika iz zakonske u naturalnu i moralnu. ${ }^{60}$ Dodatno, izrijekom je uređeno pravo poreznog obveznika na povrat plaćenog zastarjelog poreza koji to više i nije, pa, kako se radi o plaćanju duga kojemu je otpala pravna osnova, to je zbog plaćanja neduga u tim slučajevima propisano da porezni obveznik koji podmiri poreznu obvezu nakon nastupa zastare, ima pravo na povrat plaćenog poreza i pravo na kamate od dana podnošenja zahtjeva. ${ }^{61}$

${ }^{58}$ Gore opisane prakse i dvojbe u primjeni odredbi OPZ 2001. i OPZ 2008. bile su jedan od povoda ovakvog uređenja navedenim odredbama.

59 Vidi, OPZ 2017., članak 108., stavak 1.

60 Štoviše, važeći OPZ jasno propisuje da se zastarjela porezna obveza otpisuje, što potvrđuje navedeno.

${ }^{61}$ Vidi, Zheng, Junping, „Unduly-paid taxes and the protection of the taxpayer's property rigt pursuant to Article 1, First Protocol ECHR“, u: European tax Studies, 2014., No. 2, str. 27-33 (dostupno na: www.seast.it/magazine). 
Dr. sc. Nataša Žunić-Kovačević i dr. sc. Marko Šikić: Upravnopravni pojam zastare s posebnim... Zbornik radova Pravnog fakulteta u Splitu, god. 55, 1/2018., str. 231.- 250.

\section{Ukidanje relativne $i$ apsolutne zastare i pitanje duljine zastarnih rokova}

Računanje zastarnog roka kod tijeka relativne i apsolutne zastare pokazalo je nerazumijevanje ovih vrsta zastare. Naime, prema ranijem zakonodavstvu, OPZ-u 2001. i OPZ-u 2008., bila je uređena relativna zastara na način da je svaka radnja poreznog tijela usmjerena na ostvarenje prava koje zastarijeva prekidala tijek zastare tog prava nakon čega bi zastara ponovno počela teći. Zakonodavac je propisao, kako bi se spriječila mogućnost da uslijed većeg broja prekidanja zastare zastara ne nastupi, da protekom dvostrukog vremena relativne zastare nastupa apsolutna zastara. Više je razloga napuštanja navedenog razlikovanja no najjači je pronađen u čestim teškoćama utvrđivanja radnji kojima se prekida zastara te neujednačene prakse što je za posljedicu imalo veću pravnu nesigurnost poreznih obveznika. Praksa utvrđenja porezne obveze također je potvrdila nejasnoću normi i nerazumijevanje instituta. Tako je u svezi s ranije zauzetim stajalištem Visokog upravnog suda po kojem od donošenja prvostupanjskog poreznog rješenja do donošenja rješenja po žalbi relativna zastara ne teče, već samo apsolutna, iskazano nekoliko sumnji u stručnoj literaturi i sudskoj praksi. ${ }^{62}$ Naime, nastup zastare ima pravne učinke jednake prema svima i u osnovi se radi o jedinstvenom institutu s jedinstvenim pravnim posljedicama, pri čemu je zakonodavac propisao dvije vrste roka - relativni zastarni rok, koji se može prekidati i apsolutni zastarni rok, na čiji tijek ne može utjecati nositelj prava koje upravo i zastarijeva. Dakle, nastup relativne zastare i nastup apsolutne zastare imaju istovjetne pravne posljedice pa je navedeno stajalište nejasno i može svojom ,nelogičnošću“ dovesti do apsurdnih mogućnosti. ${ }^{63}$

Prednost rješenja OPZ-a 2017. jest u jednostavnijem utvrđenju nastupa zastare pa posljedično i većoj pravnoj sigurnosti. No, nedostatak bismo mogli naći u „nepoticajnoj“ normi za porezna tijela, jer je ranije zakonsko uređenje „tjeralo“ porezno tijelo poduzimati radnje na ostvarenju prava i obveze utvrđenja poreznih obveza i prava i obveze naplate poreza. Neaktivnost poreznih tijela dovodila je do zastare pa je već samo postojanje relativnog roka zastare predstavljalo poticaj na poduzimanje radnji jer je porezno tijelo poduzimanjem radnji u postupku, a sa ciljem ostvarenja svojih prava i obveza, ujedno prekidalo tijek zastare tih prava. Relativna je zastara predstavljala svojevrstan instrument ubrzanja postupka. Poredbenopravno gledano, argumenti govore u prilog novom uređenju jer većina europskih zakonodavstava ima jedinstveni pojam zastare. Pravna sigurnost također je jedan od ciljeva koji će se lakše ostvariti kroz opisano uređenje. Ipak, ostaje upitna učinkovitost poreznih tijela odnosno pitanje hoće li porezna tijela u propisanom roku ostvariti svoje temeljno pravo i obvezu - utvrditi i naplatiti porez. U složenom društvenom i gospodarskom okruženju koje je dominantno okruženje suvremenog doba, porezna tijela mogla bi opravdano zatražiti produljenje propisanog zastarnog roka. Takav put većoj učinkovitosti poreznih tijela čini se prihvatljivijim od dosadašnjih produljenja rokova pogrešnim tumačenjem i primjenom normi poreznog prava. Štoviše, pojedina zakonodavstva propisuju drugačije rokove za slučajeve

62 Vidi, Bassegli Gozze, op. cit. (bilj. 42), str. 5

63 Ibid., str. 6. 
Dr. sc. Nataša Žunić-Kovačević i dr. sc. Marko Šikić: Upravnopravni pojam zastare s posebnim... Zbornik radova Pravnog fakulteta u Splitu, god. 55, 1/2018., str. 231.- 250.

utaje poreza, dvostruko ili čak višestruko dulje. Kao neku krajnju mogućnost treba spomenuti i zakonsku mogućnost propisivanja da zastare nema, pri čemu bi, dakako, takve slučajeve zakon morao jasno i izričito odrediti.

\section{ZAKLJUČAK}

Zastara je institut koji je u pravu poznat već od rimskog doba i koji je uređen u brojnim pravnim granama, pa tako i u upravnom pravu. Uređenje zastare u upravnom pravu ima svoje posebnosti koje su vezane za posebnu prirodu upravnopravnog odnosa i određena načela upravnog prava i upravnog postupka. Smatramo kako je razumijevanje posebne prirode instituta zastare u upravnom pravu od velike važnosti jer praksa, nažalost, pokazuje kako nerazumijevanje instituta ide na štetu prava stranaka u postupku, ali i na štetu javnog interesa.

S obzirom na činjenicu da je institut zastare u posebnom poreznom pravu možda i najčišći primjer posebne upravnopravne logike uređenja instituta, u radu je navedeno područje posebno analizirano.

Prikaz historijskog razvoja i normativnog okvira porezne zastare potvrđuje uvodno primijećeno da je riječ o dobro poznatom institutu, teorijski i normativno jasno i precizno određenom što pridonosi pravnoj sigurnosti te učinkovitosti. Međutim, isti se u praksi pokazuje nedovoljno jasnim i nepreciznim pa historijat ukazuje na minuciozne zakonodavne zahvate s jednim jedinim ciljem: primjenjivačima norme pojednostaviti institut pri čemu temeljni ciljevi ne smiju biti ugroženi. ${ }^{64}$

Dakle, odredbe OPZ 2017. o poreznoj zastari nisu reprezentant kakvog velikog reformskog zahvata. Kontinuum pristupa u izmjenama, s istim ciljem - precizan, dobro poznat institut - uređen je na način da porezna administracija može isti prepoznati i primijeniti. U situaciji gdje je u poreznoj administraciji preko $90 \%$ zaposlenika nepravne struke, to se čini barem prikladnim, ako ne nužnim. Kada je riječ o sudskoj praksi, stvara se osnova za jednoobraznom primjenom norme i pravnu sigurnost. Naime, velika zastupljenost poreznih predmeta na upravnim sudovima potvrdila je neprihvatljivu nedorečenost i nejasnoće propisa o poreznoj zastari. Suprotstavljeni intresi javne i privatne stranke u poreznom postupku doprinijeli su rastu značaja i osjetljivosti na pitanje zastare $s$ obzirom na posljedice nastupa što je uz neujednačenu sudsku praksu predstavljalo povod preispitivanju postojećih stajališta i tumačenja porezne zastare kroz novi normativni okvir predstavljen $u$ OPZ 2017.

Podredno primjećujemo da raduje zaokret hrvatskog poreznog zakonodavca $\mathrm{k}$ izgradnji nove dimenzije odnosa s poreznim obveznicima. Primjena normativnog okvira zastare treba potvrditi započetu promjenu paradigme poreznog odnosa. Naime, treba istaknuti kako se od 2015. može pratiti određeni zaokret u prioritetima nositelja porezne politike. Umjesto jače porezne presije i inzistiranja na strogoj

64 Ipak, jednostavnost instituta tražila je žrtvovanje relativne zastare izmjenama 2016., unatoč brojnim zagovornicima istoga, ne samo iz krugova pravne znanosti. 
poreznoj disciplini, zakonodavac počinje davati prednost poreznom rasterećenju, stvaranju jednostavnijega i stabilnijega porezno-pravnog okvira te povećanju opće razine pravne sigurnosti poreznih obveznika. Pohvalna je orijentacija nositelja porezne politike k poboljšanju opće razine dobrovoljnog udovoljavanja poreznoj obvezi uz pomoć raznih pravnih i institucionalnih mjera koje su usmjerene izgradnji poreznopravne sigurnosti putem jednostavnih i preciznih normativnih rješenja.

Očekuje se da će primjenom OPZ 2017. predmetni, tradicionalan, „statičan“ i dobro poznati materijalnopravni institut poreznog prava ući u razdoblje jednoobrazne primjene što će omogućiti ostvarenje poreznopravne sigurnosti.

\section{Literatura:}

1. Bassegli Gozze, Vlaho, „Institut zastare u hrvatskom poreznom pravu dugogodišnja otvorena pitanja i mogući odgovori na njih", Sveske za javno pravo, Fondacija Centar za javno pravo, br. 8, 2017.

2. Borković, Ivo, Upravno pravo, Narodne novine, Zagreb, 2002., str. 552.

3. Đerđa, Dario, Opći upravni postupak u Republici Hrvatskoj, Inženjerski biro, Zagreb, 2010.

4. Giunio, Miljenko Appio, „Zastarijevanje tražbine, zastara i posljedice - opća i neka izabrana pitanja“, u: Liber amicorum Petar Klarić, ur. Josipović, Tatjana, Gliha, Igor, Baretić, Marko i dr., Pravni fakultet Sveučilišta u Zagrebu, Zagreb, 2012.

5. Gordon K., Richard, „Law of Tax Administration and Procedure“ u: Tax Law Design and Drafting, Vol I, ed. By Victor Thuronyi, IMF, Washington, D. C. 1996.

6. Greggi, Marco, Žunić Kovačević, Nataša, „Lights and Shadows on the Implementation of the Alternative Dispute Resolution (ADR) system in the Italian and Croatian Tax Trial"“, Zbornik Pravnog fakulteta Sveučilišta u Rijeci (1991.), v. 38, br. 1, 377-396 (2017.).

7. Horvat, Ladislav, „Posljedice zastare u porezno-pravnom odnosu“, Zbornik radova znanstvenog skupa „Hrvatska pred vratima EU - fiskalni aspekti“, HAZU, Zagreb, 2005.

8. http://www.upravnisudrh.hr/frames.php?right=odluke.html. (10. IX. 2017.).

9. Jenjić, Jasminka, Orlić Zaninović Senka, Posebnosti upravnog postupka u poreznim stvarima, Pravosudna akademija, Zagreb, 2016.

10. Juričić, Mirjana, „Zastara u poreznim stvarima“, Upravno pravo - aktualnosti upravnog sudovanja i upravne prakse, 2008., Inženjerski biro.

11. Klarić, Petar, Vedriš, Martin, Građansko pravo, Narodne novine, Zagreb, 2006.

12. Krapac, Davor, Kazneno-procesno pravo, Narodne novine, Zagreb, 2007.

13. Kriletić, Marija, ,Zastara naplate carine i prekršajnog progona u praksi Upravnog suda Republike Hrvatske“, Upravno pravo - aktualnosti upravnog sudovanja $i$ upravne prakse, 2008., Inženjerski biro.

14. Krneta, Slavica, Odabrane teme privatnog prava, Pravni fakultet Univerziteta Sarajevo, 2007. 
Dr. sc. Nataša Žunić-Kovačević i dr. sc. Marko Šikić: Upravnopravni pojam zastare s posebnim... Zbornik radova Pravnog fakulteta u Splitu, god. 55, 1/2018., str. 231.- 250.

15. Medvedović, Dragan, „Bitne razlike novog Zakona o općem upravnom postupku prema prijašnjem Zakonu o općem upravnom postupku“, u: Primjena Zakona o općem upravnom postupku, Novi informator, Zagreb, 2010.

16. Opći porezni zakon, NN 127/2000, 86/2001, 150/2002.

17. Opći porezni zakon, NN 115/16.

18. Opći porezni zakon, NN 147/2008, 18/2011, 78/2012, 136/2012, 73/2013, 26/2015, 44/2016, 115/2016.

19. Pravni leksikon, Leksikografski zavod Miroslav Krleža, Zagreb, 2007.

20. Romac, Ante, Rimsko pravo, Pravni fakultet, Zagreb, 1998.

21. Rostaš-Beroš, Lidija, „Porezna zastara u praksi upravnih sudova“, Novosti $u$ upravnom pravu i upravno-sudskoj praksi, Savjetovanje 2013., Narodne novine.

22. Selicato, Pietro, L'attuazione del tributo nel procedimento amministrativo, Milan, Giuffrè, 2014.

23. Šikić, Marko, Ofak, Lana, „Nova načela upravnog postupka (s posebnim naglaskom na razmjernost, legitimna očekivanja i stečena prava)“, Zbornik Pravnog fakulteta Sveučilišta u Rijeci, 1(2011.).

24. Šikić, Marko, „Zaštita pravne sigurnosti stranaka u upravnom postupku“, Zbornik Pravnog fakulteta Sveučilišta u Rijeci, 1(2014.).

25. Vanistendeal, Frans, „Legal Framework for Taxation“ u: Tax Law Design and Drafting, Vol I, ed. By Victor Thuronyi, IMF, Washington, D. C. 1996.

26. Visković, Nikola, Teorija države i prava, Birotehnika, Zagreb, 2001.

27. Vrban, Duško, Država i pravo, Golden marketing, Zagreb, 2003.

28. Vukić, Nikola, „Zastara potraživanja poreza u Republici Hrvatskoj“, Tendencije u razvoju financijske aktivnosti države, Zbornik radova sa Znanstvenog skupa povodom 100. obljetnice tiskanja knjige Stjepana Posilovića „Financijalna znanost", HAZU, Zagreb, 2000.

29. Zakon o državnim službenicima, NN 92/2005, 140/2005, 142/2006, 77/2007, 107/2007, 27/2008, 34/2011, 49/2011, 150/2011, 34/2012, 38/2013, 37/2013, $1 / 2015,138 / 2015,61 / 2017$.

30. Zakon o općem upravnom postupku (NN 47/09).

31. Zheng, Junping, „Unduly-paid taxes and the protection of the taxpayer's property rigt pursuant to Article 1, First Protocol ECHR“, u European tax Studies, 2014, No. 2.

32. Žunić Kovačević, Nataša, „Zastara - o primjeni građansko-pravnih pravila u poreznom pravu i sudska praksa“, Zbornik Pravnog fakulteta Sveučilišta u Rijeci, 1(2009.). 


\title{
ADMINISTRATIVE CONCEPT OF STATUTES OF LIMITATIONS WITH PARTICULAR ATTENTION TO STATUTES OF LIMITATIONS IN TAXATION LAW
}

\begin{abstract}
After the introduction in which the institute of statute of limitations is analysed briefly in legal theory and certain legal branches, an attempt is made to point out the specifics of regulating the institute of statute of limitations in administrative law. Thereto, the fact that the public legal bodies in administrative relations are in a superior position to other participants in that relation is particularly emphasised. Also, certain principles of administrative law are mentioned as being particularly important to understanding the peculiarities of the institute of statute of limitations in administrative law. The middle and main part of this paper is dedicated to analysis of the institute of statute of limitations in taxation law through chosen examples from court practice wherein the main attention is given to normative amendments of the institute of statute of limitations made by provisions of the latest general taxation law. In conclusion, basic theses of this paper are briefly mentioned with the hope that application of this new law will lead to achieving taxation predictability and certainty.
\end{abstract}

Key words: statute of limitations, administrative law, taxation law, court practice, General Taxation Law 